\title{
Encounter and Engagement \\ Negotiating Otherness in the Dutch Protestant \\ Development Cooperation Network in Brazil
}

\author{
João Rickli \\ PUCRS
}

\begin{abstract}
This article investigates encounters occurring in the development cooperation network facilitated by two Dutch Protestant agencies - ICCO and KiA - in Brazil, focusing on the process of negotiating otherness inherent to development initiatives. The text is based on multi-sited ethnographical research conducted in Brazil and in the Netherlands. In its first section, the text introduces the two organisations, highlighting the overlap between religious and secular moralities in their discourses and practices. The second section describes a meeting they promoted with their partners in Brazil, analysing how a grammar of difference is mobilised by the actors to make sense of the world and of the "far-away" other, creating what could be called cosmologies of development cooperation. The text focuses mainly on how concrete interactions influence these cosmologies, actualising, reproducing or contesting them in practice.
\end{abstract}

Keywords: otherness; development cooperation; engagement; network; power

\section{Resumo}

Este artigo investiga encontros ocorridos numa rede de cooperação para o desenvolvimento organizada por duas agências holandesas, ICCO e KiA, no Brasil, focando no processo de negociação da alteridade inerente a iniciativas de desenvolvimento. $O$ texto é baseado em pesquisa etnográfica multi-situada realizada no Brasil e na Holanda. A primeira seção introduz as duas organizações, destacando a superposição entre moralidades religiosas e seculares em seus discursos e práticas. A segunda seção descreve uma reunião promovida com seus parceiros no Brasil, analisando como uma gramática da diferença é mobilizada pelos atores para fazer sentido do mundo e do "outro distante", 
criando o que poderia ser compreendido como cosmologias da cooperação para o desenvolvimento. $O$ texto aborda principalmente como interações concretas influenciam estas cosmologias, atualizando-as, reproduzindo-as e contestando-as na prática.

Palavras-chave: alteridade; cooperação para o desenvolvimento; engajamento; rede; poder 


\title{
Encounter and Engagement \\ Negotiating Otherness in the Dutch Protestant \\ Development Cooperation Network in Brazil1
}

\author{
João Rickli \\ PUCRS
}

\section{Introduction - otherness and development}

In April 2007, $\mathrm{ICCO}^{2}$ and Kerk in Actie - KiA (Church in Action), the two most important Dutch Protestant agencies for development cooperation, brought their entire list of partner organisations in Brazil together for a meeting in the city of Salvador, Bahia. During three days, some dozens of representatives of partners, a delegation of nine staff members from different ranks of ICCO and $\mathrm{KiA}$, and a group of external experts invited to observe and comment gathered in a Catholic venue on the famous beach of Itapoã. They discussed ICCO and KiA action in Brazil for the coming years and some important organisational changes that were happening in the development network at that very moment as an outcome of the establishment of an alliance between the two Dutch organisations.

At the end of the first evening of the event, the participants joined an activity defined as a "spiritual moment", led by the representative of an organisation supported by KiA. It began with a Brazilian religious song that was very popular in the ecumenical movement. The lyrics invite people to entrar na roda (join the circle), work together and transform the world 3 . A circle was formed and people were asked to close their eyes and think about the face of

1 This article is based on my PhD dissertation Negotiating Otherness in the Dutch Protestant World: Missionary and Diaconal Encounters between the Protestant Church in the Netherlands and Brazilian Organisations (Rickli 2010), defended at the VU University Amsterdam. I would like to thank Victoria Irisarri and all members of the research group SobreNaturezas (sobrenaturezas.blog.br) for their precious comments and suggestions.

2 ICCO was the abbreviation for Interkerkelijke Coördinatie Comissie Ontwikkelingssamenwerking (Interchurch Coordination Committee of Development Cooperation). The organisation has changed its name to Interkerkelijke Organisatie voor Ontwikkelingssamenwerking (Interchurch Organisation for Development Cooperation), but kept the old abbreviation, more widely and commonly used than its actual name.

3 The name of the song is "Momento Novo" (New Moment) and the main image in the lyrics is that of God calling people to walk side by side and together build this new moment. 
one person who motivates them to go on with their fight against injustice. After a few moments in silence, the coordinator incited people to raise an arm to point to "every corner of Brazil" and speak out the name of this person. Common names - João, Severino, José, Maria, Aparecida - with no last name popped up in the group, names of ordinary people (gente do povo), in the words of the leader. The "spiritual moment" ended with another song, a popular composition by Dorival Caymmi, a famous musician from Bahia, about fishermen going to the sea in their small boats, praying for good fish.

This article investigates interactions and encounters occurring in the development cooperation network facilitated by two Dutch Protestant agencies - ICCO and KiA - in Brazil, focusing on the process of negotiating otherness inherent to development initiatives. I argue that endeavours aiming at improving other people's lives must necessarily frame, define and, in a certain level, imagine the other, the targets of development work. In doing so, development endeavours must draw a line separating "us" and "them", organising the terms of the difference between a developed self and a developing other. Producing and negotiating this difference is a fundamental task in development networks. The ethnographic vignette I presented above brings an eloquent image of these negotiations: a circle of Dutch and Brazilian development workers invoking faces and names of their others, the "common people that motivate the fight against injustice".

In the case of Dutch Protestant development networks, the process of negotiating otherness is closely connected to religious feelings and ideas. This is another topic the vignette touches upon, being an example of how Christian liturgies, songs, discourses and values permeate ICCO, KiA and their partners' routines and activities. Many authors have recently pointed to the religiosity that is more or less inherent to the kind of moral discourses conjured by any kind of development initiative (see, for instance, Salemink, Harskamp and Giri 2004 and Quarles van Ufford and Giri 2003), even when these discourses are phrased in secular terms. Although the independence in relation to religious contents is a condition projects quite often have to fulfil in order to receive financial and institutional support from governmental and multilateral agencies, a considerable part of these projects is designed and implemented by organisations closely connected to churches or ecumenical movements. Their accommodation within the secular governmental apparatus, or their inclusion in large-scope networks of "Northern" 
development agencies, is based on the overlap of Christian and secular moralities of peace and justice.

In the case of ICCO and KiA, the relationship between development values and Christianity is extremely important, insofar as development cooperation is performed together with missionary and diaconal work by organisations and committees that are very often united under the abbreviation ZWO - zending, werelddiaconaat and ontwikkelingssamenwerking (mission, world-diaconate and development cooperation). Differences and divisions among these three domains vary a lot, depending on many factors, as I will describe later. For now, however, it is enough to say that, for the Protestant churchgoers, the ZWO conundrum is perceived as one sole endeavour, whose distinctive character is precisely its orientation towards the "far-away other", these people that must be converted, helped, improved, supported, known, heard or loved, depending on the religious/secular repertoires invoked to make sense of the actions $s^{4}$.

The third issue the vignette introduces relates to methodological choices and the type of empirical data to be present in this article. The text focuses on ordinary interactions between real actors, analysing how otherness is constantly negotiated in meetings, encounters, bureaucratic procedures and rituals that give concreteness to the otherwise abstract idea of development cooperation. In doing so, I emphasise the processual character of otherness, seeking to avoid a fixed grammar of cultural differences that is often invoked in official documents and discourses.

In my PhD dissertation (Rickli 2010), I have analysed how documents bearing missionary and developmental policies and discourses are designed to be interpreted as sources of concepts and ideas that give shape to the

4 The definitions of the differences between mission, diaconate and development cooperation are object to debates and can be quite diverse among the Dutch Protestants. Briefly I would like to point out here as a provisional definition, that the terms "diaconate/diaconal" refer to all services that the church provides to the society that surrounds it, often without an explicit religious and Christian discursive content. Missionary work can be distinguished from diaconate because it is directly linked to the testimony of the Christian faith, and to themes such as conversion to Christianity and inter-religious dialogues. Development cooperation relates in general to projects that have a very distant relation with religion, having often no other connection to the church than the financial support received from KiA or ICCO. In interviews with churchgoers in the Netherlands, it became clear that these differences were not considered important, being no more than a matter of quantities of religious or secular ingredients used, following slightly different recipes, for the preparation of the same dish: Christian responsibility toward the far-away "other". 
action to be performed by the organisations that produce them. Because of this specific programmatic nature, function and discursive structure, they tend to hide the inherent connection their production has with daily practical experiences. In placing themselves as sources of meaning and guidelines to the work that will be implemented in their wake, they tend to neglect the role played by the existing web of relationships and links in the process of producing these guidelines. They mobilise different symbolic repertoires from anthropological knowledge to the Bible, from academic theology to the Millennium Development Goals - to organise their narratives through a logic of cause and consequence, overlooking the fact that, in addition to these repertoires, these narratives are also grounded on experiences and encounters that occur before their elaboration and that nourish these repertoires.

The main consequence of this fact is that the panorama that emerges from official documents of mission and development evokes a world of relatively clear-cut conceptual boundaries, in which there is not much room for blurred, chaotic and often confusing contacts between the diversity of actors involved in this type of transnational network. In official documents and narratives, the complexity of development cooperation networks is organised and often simplified, giving rise to a series of generalised abstractions. One of these abstractions relates to the core issue of this article: the clear-cut line separating those who promote development and those who must be developed. This way of organising and simplifying the world, whatever vocabulary it mobilises (theological, philosophical, anthropological), invokes a grammar of differences that becomes an overarching and all-encompassing framework to make sense of the world of development and mission.

In the present article I try to avoid taking this grammar of differences for granted, analysing how it is negotiated in extensive and minute interactions occurring in the daily life of the network. Instead of building on an intangible difference between a developed self and a developing other, explicit in dichotomies such as "North/South" and "top-down/bottom-up", and implicit in images like "frontiers", "borders" and "translation", I am using ethnographic data to present the encounters as disordered, chaotic and complex experiences. Beyond the image of the world as a patchwork of cultures, whose borders people cross to encounter the "other", there is the constant work of ordering (Law 1994: 9) blurred, confusing and fluid experiences occurring in a continuous world (Ingold 1993: 228). This work mobilises categories picked up 
from different symbolic repertoires to create a temporarily stable cosmology of boundaries, which have to be re-enacted on a daily basis. In other words, the differences that inhere in the interactions I look at in this text will not be a tool to explain development encounters but, as an important component of the development cosmology, one of the things that needs to be understood. This article is composed of two main sections and a conclusion. The first one introduces ICCO and KiA and describes the process of forging the ICCO Alliance, an organisational change that deeply affect both organisations and that motivates the meeting in Salvador, which is the narrative axis of the article. The second section focuses on the meeting, describing its first evening and analysing a few aspects of the process of negotiating otherness.

\section{$\mathrm{KiA}$, ICCO and the new Alliance}

Before presenting and analysing the meeting between the Dutch Protestant organisations and their partners in Brazil, I am compelled to introduce these organisations and say a few words about the processes they were going through at the time of the meeting. The Dutch Protestants I refer to in this text are people and organisations belonging to the Protestantse Kerk in Nederland - PKN (Protestant Church in the Netherlands), the biggest and most important Protestant church in the country. PKN was founded in 2004 as a result of the merge of the two most traditional Dutch Reformed churches and the small Dutch Lutheran community. PKN is recognised as the main heir of the predominantly Calvinist Reformation in the Netherlands 5 .

As I mentioned above, for PKN members activities related to development cooperation are regarded as part of their duties towards the "far-away other", organised under the abbreviation ZWO (mission, world-diaconate and development cooperation). Designing and implementing ZWO work are attributions of two central organisations: KiA and ICCO, which since January

5 For a general view on the history of the PKN and its position in the religious panorama of the Netherlands, see Sttofels (2008), which provides an accurate and analytical view on the establishment of the new denomination. For a detailed (and enthusiastic) picture of the long process of merge, see Wallet (2005). The book edited by Sengers (2005) brings a good overview of important aspects of the Dutch religioscape. 
2007 joined the so-called ICCO Alliance ${ }^{6}$. The Alliance is the central node of an extensive network, which includes a varied gamut of "Southern" partner organisations (NGOs and churches, mainly); other "Northern" NGOs and development agencies that cooperate in specific projects and partnerships; and also a great number of local and regional committees in the Netherlands, which are responsible for promoting ZWO activities, raising funds and attention to projects and partnerships related to mission, world-diaconate and development cooperation.

The most substantial part of ICCO Alliance's current work abroad consists in supporting partner organisations in different parts of the world for a determined number of years. The Alliance also sends different kinds of professionals to work abroad as expatriate social workers (or missionaries), most commonly in cooperation with local partners. According to the ICCO Alliance Operational Plan (ICCO, 2006), the majority of projects and partnerships are accommodated in four different programs: Duurzame Rechtvaardige en Economische Ontwikkeling - DREO (Sustainable Fair Economic Development), Democratisering en Vredesopbouw - D\&V (Democratisation and Peace Building), Toegang tot Basisvoorzieningen - TtB (Access to Basic Facilities) and Zending - Z (Mission). Some smaller programs dealing with specific issues, such as microcredit and some specific educational initiatives, did not fit this thematic division and remained independent unities inside the Alliance. Besides these more stable and long term forms of operating, the organisation also manages a program of emergency aid that acts in cases of natural disasters or extreme humanitarian crises.

$\mathrm{KiA}$ is the dienstenorganisatie (service organisation) of the PKN and it is directly connected to the church's bureaucracy. KiA's guidelines, policy documents and main decisions have to be approved by the synod of the chur$\mathrm{ch}$, and the organisation's main source of funding is the donations of PKN parishes. Heir of different missionary and diaconal departments of different religious denominations and communities, KiA was established in 1994 in one of the kaleidoscopic moves that have constantly changed the configuration of the field of mission, diaconate and development in Dutch Protestant

6 Four other much smaller organisations also joined the Alliance: Edukans, Oikocredit, Share People and Prisma.

7 The missionary program is the only one that is managed exclusively by KiA, being not part of the ICCO Alliance. 
circles. The most important organs that formed KiA were those connected to the three denominations that would later join PKN, but other small Christian groups have also adhered to the new organisation, such as the Remonstrant Brotherhood, the Salvation Army and the Old Catholic Church. Before joining the Alliance, KiA was a relatively small organisation. According to KiA's annual report (Kerkinactie, 2006), in 2006, the last year it KiA and ICCO operated separately, it had a budget of about 50 million euros destined to projects in 75 different countries around the world. At the time, KiA had 110 employees in the Netherlands that, given the high number of part-time workers, added up to a bit more than 76 full-time positions (fte's).

ICCO, in its turn, was more than three times as big as KiA, managing a budget of 160 million euros and about 347 employees (the equivalent of 222 full-time positions). It is historically linked with the Protestant denominations that originated the PKN, but it is quite independent from church bureaucracy and it is funded almost exclusively by the Dutch government. ICCO (or since 2007, ICCO Alliance) is one of the members of the select and prestigious group of organisations that had access to the billionaire budget of the Ministry of Foreign Affairs of the Netherlands. Regarding development cooperation, the Dutch government is widely recognised as one of the biggest donors in the world, and its Ministry of Foreign Affairs has a powerful department for handling international development issues, which is known as Ministry of Development Cooperation. This Ministry develops its own projects through the Dutch embassies all over the world, but most of its budget is expended through donor NGOs such as ICCO, which have their own projects, partners and networks.

A change in the rules for applying for the Ministry of Development Cooperation funds was the main reason behind the approximation between KiA and ICCO that finally led to the forging of the Alliance, in 2007. Following international neoliberal tendencies, during the 2000 s the Ministry created new rules for applying for funds, broadening the spectrum of organisations that could be eligible and stimulating greater competition among them. I will not describe in detail the quasi-hypnotising bureaucratic documents of the ministry, but only mention one of these rules that had the greatest impact in the processes I am describing here. This rule stipulated that the organisations applying for funding find their own means to raise twenty-five percent of the budgets they present to the Ministry. Thus, agencies that 
for decades had been almost exclusively funded by the government suddenly had to prove that they would be able to come up with one quarter of all the resources they needed on their own. ICCO never had a strong relationship with the general public, Protestant or not, and therefore, it had a rather limited fundraising capacity and expertise. The solution, thus, was to find partners with experience in this field and, yet more important, a faithful body of supporters. KiA was, of course, a natural choice. Besides the fact that they share the same roots, the PKN in general, and KiA in particular, were facing a constant decrease in financial resources, as a consequence of the continuous and strong "de-churching" of Dutch society ${ }^{8}$. Moreover, PKN and KiA offices had recently moved to a new and far too big building in Utrecht, whose maintenance costs proved to be higher than expected and the idea of uniting efforts and sharing costs with the much richer ICCO seemed to be a feasible way of solving at least part of their financial problems. Thus, both partners had good reasons for joining the Alliance.

Bureaucratically, the alliance was made possible on the basis of two major conditions. First, the application for Ministry funding was submitted by the ICCO Alliance as a whole, with only one budget and one policy document to be assessed by the Ministry, namely, the ICCO Alliance Operational Plan. This document united budgets and actions of both partners. Second, in order to preserve the separation of church and state, and avoid the spending of public money on religious activities, KiA's mission department did not become a full-fledged member of the Alliance, but maintained its own independent policy document which was not submitted for governmental appraisal. From the church's point of view, there was also some suspicion in operating with state money, and therefore, the synod of the PKN approved the Alliance under the condition that, in spite of the common policy guidelines approved by the ministry, ICCO and KiA projects and budgets should be kept separate, meaning that public and church money should follow different paths inside

8 My preference for the expression "de-churching", instead of "secularisation, is based on the findings of the extensive research project called Between Secularisation and Sacralisation, coordinated by Prof. André Droogers, at the VU University Amsterdam. For a provisional account of the main findings of the group, see Droogers (2007). A more quantitative approach, supporting the secularisation paradigm can be found at large scope studies about religion in the Netherlands, such as long term research project God in Nederland (Dekker, Hart and Peters 1997 and Bernts, Dekker and Hart 2007) and the report Geloven in het Publiek Domein (Donk et al. 2006) of the Wetenschappelijke Raad voor het Regeringsbeleid - WRR (Scientific Committee for Governmental Policies). 
the Alliance. The process of forging the Alliance, thus, was not a fusion of the organisations, but more an amalgamation.

\section{ICCO Alliance and its others - the meeting in Salvador}

Explaining the forging of the ICCO Alliance to Brazilian partners was one of the main objectives of the meeting in Salvador between a delegation of staff members of ICCO and KiA and representatives of almost all ICCO Alliance's partners in Brazil, in which the "spiritual moment" I described in the opening of this article took place. The other goals were: (1) clarifying the outcomes of the new Operational Plan; (2) consulting partners on the general plans and strategies of ICCO and KiA within the country; (3) discussing the long term implementation of a new agenda for decentralisation and shared responsibilities with the "South"; and (4) discussing the policy document for Brazil.

In order to introduce the main points of my argument, I will use a narrative of the first evening, which anticipated most of the tensions and negotiations that took place along the whole event, complemented by some observations made in the two days that followed. Despite its extraordinary character, the meeting in Salvador exemplifies situations and dynamics that I observed in many different occasions during my fieldwork, which allows me to take it as a critical event and narrative axis of this article.

The meeting in Salvador started with a speech by the chair of the Alliance delegation, the head of one of the Alliance's thematic programs. He welcomed all participants, listed the objectives of the event, as mentioned above, and summarily introduced the main changes in policies and strategies of the ICCO Alliance in Brazil that would be discussed over the following days. His talk, further developed in a longer presentation the next morning, highlighted the link between the direct goals of the meeting and changes in Dutch government policies concerning development cooperation. He gave especial attention to the implementation of the new methodological framework described in the Operational Plan. In his view, the "chain approach" and the decentralisation of decision-making were means to make cooperation more effective, responding to the stricter rules imposed by the Dutch Ministry of Foreign Affairs for assessment of the quantitative balance between inputs and outputs in development initiatives.

As the chair of the Alliance delegation and the highest representative of 
the ICCO hierarchy present in Salvador, he performed the role of official host of the event. In this opening speech, he welcomed guests and expressed his appreciation for the fact that they all had managed to respond to the invitation. Two days later, in the last plenary, he was the one responsible for pronouncing the closing words, thanking participants for their contributions and summarising and assessing the main results of the meeting. Except for a few questions and comments that he made in some of the sessions, whenever he addressed the participants he was sitting at a table placed in front of the audience, while the facilitators and other presenters were always standing and walking around the room, where most of the time people were seated in a circle. This position gave an official and formal character to his interventions. Furthermore, that was his first time in Brazil and he was the only member of the Dutch delegation addressing the plenary in English, with an interpreter who translated his words, followed him around and translated presentations and discussions for him.

His inexperience with Brazilian issues and his lack of command of the language certainly contributed in creating a significant distance between him and his guests. The need for an interpreter for his not so frequent interventions and his formal way of addressing the audience, in contrast to other presenters, created some difficulty and awkwardness in his interactions with representatives of the Brazilian partner organisations. This general feeling of distance was reflected in the way the participants referred to him in small talk and conversations during breaks: the chefão (big boss).

After the opening speech rendered by the head of the Alliance delegation, the two Brazilian professionals hired to facilitate the meeting took over. They began by proposing an experiential group activity to get people acquainted with each other and to increase solidarity and cooperation. It consisted of walking around the room greeting the other participants in both usual and less usual, comical ways determined by one of the facilitators, who was playing the guitar and singing. Every time he stopped singing, participants were supposed to share a few words, in pairs, expressing their expectations regarding the meeting and relating whatever anecdotes they had on their relationship with ICCO.

After this icebreaker, there were three more points on the evening's schedule. The first was the interactive elaboration of two lists, one listing all the conditions that would be necessary for the event's success and another 
suggesting what should be avoided to achieve that same goal. The main points emerging in the former were: objectivity, transparency, respect for different positions, clearness, openness and full knowledge about what the Alliance had already decided and what could still be changed in the documents to be discussed. The negative list mentioned: unilateral views and positions, repetitive interventions, delays in resuming activities after coffee breaks and answering mobile phones during the meeting.

The next activity was the presentation of the schedule of the next two days, prepared by the facilitators in consultation with ICCO. The presentation also included the election of a person to represent partner organisations within the committee that would provide daily assessments of the progress of the discussions and make whatever changes became necessary in the schedule of activities. Some disagreement about the proposed election procedures led to a long, hard discussion about the very nature of the meeting, unleashing conflicts and clashes that marked the whole event. On the one hand, some of the Brazilian participants, particularly those representing the big, highly professionalised and highly politicised NGOs, attributed a lot of importance to positions on the evaluating committee, insofar as it was the only opportunity offered partner organisations to have some effective power on decisions related to the meeting schedule. Thus, they wanted better elaborated election procedures, with more transparency, more time to negotiate candidacies and some room for a proper presentation of the candidates, since the meeting was just beginning and most people had not yet gotten to know each other. On the other hand, the Dutch delegation apparently tended to see the election more as a formality and the committee was not considered important enough to justify time-consuming discussions and procedures for the election.

Organisers' resistance in accepting partners' proposals to change election procedures triggered questions about the format of the event. Brazilian organisations wanted to know exactly when there would be room for the discussion of the new methodologies and documents and, more important, to which extent their critical comments would really be taken into account. They manifested their suspicions that the meeting was only a means to legitimise, as democratic and decentralised, a package of decisions that had already been made in the Netherlands without the partners' participation. Thus, the election was taken as an example confirming their suspicions, since the 
ICCO Alliance refused to accept partners' demands regarding something as trivial as an election for an ad hoc committee.

One of the ICCO delegation members calmly but firmly reminded everybody that the ICCO Alliance was the organiser of the event, and therefore, its delegation had the final word on how to proceed. He explained that the chain approach, the main change in the Alliance's methods at issue in the meeting, had already been definitively adopted, as stated in the Operational Plan approved by the Dutch government. The general frame of the action in Brazil, as explained in the ICCO policy document for the country, would not change structurally although questions about it would be welcome the next morning, from 10.45 to 12.30 , in the plenary session coordinated by the head of the ICCO delegation. Then he clarified that the contribution the Alliance expected from partners was to be formed by their views and ideas about the implementation of the chain approach in relation to the Brazilian situation as a whole and to their specific organisational contexts. The core of the action would not be negotiated. With the remark that time was precious, he said that despite the protests, the election would proceed as planned. Reluctantly, everybody voted.

The long debate around the election caused a deviation from original plans and an accumulated delay of about one hour in the schedule. The words of the ICCO representative, reminding how precious time was and stipulating an appropriate and precise moment for the questions that were being raised (from the point-of-view of the organisers) at the wrong moment, represented an attempt to regain control of routines and to prevent long digressions and improvisations. Finally, then, the participants proceeded to the last activity of that evening: the "spiritual moment" I presented in the introduction of this article, in which faces and names of the people that would benefit from development work were evoked.

In order to analyse the encounter in Salvador, I will highlight two different and competing images related to otherness being constantly conjured by organisers and participants. The first was visible in the experiential activities, in the rhetoric of partnership and cooperation, in the common commitment celebrated during spiritual moments (they took place every day) and in the images of unity and solidarity: we are all on the same circle, colleagues struggling together to improve the lives of our common "other". The central image, here, is sameness and continuity between the different parties of the 
meeting, produced in relation to Marias and Severinos, whose benefit is the ultimate goal approximating Northern donors and Southern NGOs.

The second image focused on otherness rather than on sameness, establishing a clear-cut boundary between the two groups represented in the meeting. It created an opposition between organisations in the "South" and the cooperation agency in the "North", mobilising a series of overlapping dichotomous images and stereotypes: Europe (Holland) x South America (Brazil), Dutch culture $x$ Brazilian culture, givers $x$ receivers, rich $x$ poor, and so on. This clear image of difference was not only explicit in the conflicts that broke out, but was also implicit in the format of the event, in which the organisers - the Dutch delegation - hosted some dozens of partners that, as guests, were supposed to accept the terms of the encounter promoted by the hosts. In Salvador, the opposition hosts/guests (organisers/participants) governed the practicalities of the distribution of power during the meeting. It overlapped with the opposition givers/receivers.

The Dutch delegation and the Brazilian partners enacted these images of identity or difference in their own specific ways. The Brazilian organisations, among which the representatives of the big NGOs immediately took over the position of spokespersons for the whole group, expressed difference in relation to the Alliance delegation through the images of Brazilian culture, people and poverty that they evoked, acting as their authorised representatives. This evocation of the target of their organisations' actions occurred not only in spiritual moments, but also during discussions and meetings, especially vibrant when participants attempted to make their position stronger and more legitimate in divergences and confrontations with the representatives of the ICCO Alliance. In these moments, sentences such as: “you don't know the situation there, in the favelas, as I know"; or "you wouldn't say that if you stay for a few months in the rural village I'm working in right now" served to stress the difference between the distant world of ICCO Alliance and the daily routines at the local level.

Moreover, making use of traditional repertoires of Brazilian leftist social movements, representatives of the partner organisations sometimes claimed for themselves the position of the oppressed and excluded from power, while the Alliance was referred to as the "cash holders" (donos da grana), as I often heard in informal (and sometimes rather conspiratorial) talks during the breaks. They stressed their contiguity to the delegation's “other”, performing 
this role and stressing the distinction between the powerful givers from the "North" and the poor and powerless receivers in the "South". At these moments, they embodied Brazilian poverty and the meeting was enacted as an encounter with the other.

However, in other moments, they evoked people and topics related to poverty and to the work they perform in their own organisations in order to produce a sense of unity in relation to the objectives of network action as a whole. Poor people in Brazil, thus, could also be evoked as a sign of the existence of a common "other", people that depend on the concerted efforts of mission and development professionals. At these moments, claims for power and influence on decision-making processes related to the network were linked to professionalization, efficiency and partnership with their Dutch "colleagues". Their plea, then, was to make the meeting an encounter of professionals discussing a common "other". Thus, their engagement (Ingold, 1993: 220) in the meeting oscillated between the embodiment of Brazilian "otherness" and the performance of shared efficiency and professionalism.

The leaders of the Dutch delegation addressed images of difference and identity from another perspective. They fluctuated between the discourse of partnership, which was the motive of the meeting, and an appeal to the binomial organisers/participants which they employed whenever they needed to justify the fact that it was they who had the final word regarding issues discussed and procedures put into practice. The performance of Alliance hospitality, with the head of the Alliance delegation in the leading role, framed the experience of encounter as a reunion of partners with shared objectives who would together discuss how to implement the newly designed methods to achieve them, yet within the terms proposed by the ICCO Alliance, as meeting organiser and host. Activities should follow a predetermined schedule conducted by the facilitators, but controlled by Alliance staff. The paradoxes implicit in this proposition encapsulate the switch between the images of sameness and otherness enacted by the members of the Alliance: on the one hand, they genuinely intended to create an atmosphere of unity and commonality with partners; on the other hand, the differentiated positions of givers and receivers was implicit in the performance of hospitality and consequent authority over meeting procedures.

These two different ways of invoking identification and difference point to the core aspects of negotiating otherness at issue in this article. Beyond 
the grandiloquent theological and moral statements present in official documents, negotiating otherness is related to the diverse ways of engaging with actual encounters. Mutatis mutandis, the idea of engagement here resonates with the processes Ingold described in relation to perception "as the ongoing activity of the whole person, moving around in - and exploring - an environment, and seeking out what it affords in the context of current projects" (1993: 220 italics in the original). The grammars of difference expressed in the official documents are accepted or contested, reproduced or transformed according to the various micro-level relationships developed during encounters between whole persons engaging in interactions, governed not only by religious or moral rationales, but also by the senses and the emotions. That is why a deeper understanding of the network can only be achieved through an analysis that goes beyond its theological and philosophical bases.

In this sense, the different ways of oscillating between sameness and otherness demonstrated by representatives of partner organisations and ICCO Alliance staff members could be regarded as an expression of the complex, fluid and often paradoxical positions and relations that inhere the actual encounters between whole persons in the environment of development cooperation. Therefore, an important part of this kind of meeting is to accommodate these complex and paradoxical interactions in that grammars of difference that order, explain and simplify the world, rendering it into something approachable and apprehensible.

In the Salvador meeting, a variety of factors related to the engagement with the encounter led to the contesting of the way the Dutch delegation proposed to accommodate the complexity of the interactions in an ordered frame. First of all, the distance established between the head of the Alliance delegation as the main character of the host/guest performance and the Brazilian partners present at the meeting generated a gap between the tangible experience of interacting with him and the message he was trying to convey. This distance, expressed in the image of the "big boss", was constructed through bodily attitude, small and prosaic interactions, and the fact that he does not speak the country's language. His way of engaging with the moment of the encounter, mediated by an interpreter, speaking behind a table that served to differentiate his position, contradicted the very images of partnership, decentralisation and horizontal relationships he was supposed to support. 
Thus, it was not only the previous existence of a structural difference between givers and receivers that inexorably led to the contestation of the terms proposed by the Alliance. A point of equilibrium between images of sameness and otherness, whose formulations seemed to be inherent to the meeting, had to be re-produced in loco, by whole persons engaging with the encounter. This delicate balance would be found not only in the official discussions and dialogues, but also (and perhaps primarily) in the microscopic dynamics of being together. One more ethnographic example can clarify this point.

The head of the Alliance delegation, acting as host in a country he had never been to, could not help but delegating all practicalities of the hosting position to somebody else. The details of the meeting were dealt with by CESE staff members, a large NGO based in Salvador, in direct contact with one of ICCO's most experienced relationship managers linked to Brazil, also the meeting's main practical organiser. The power of micro-level personal commitments and debts (in the Maussian sense), as created in the daily exchanges between hosts and guests, was therefore not accessible to the head of the Alliance delegation. The empathy, solidarity and engagement that could result from the liturgies of hospitality were solemnly ignored by the Alliance. In the end, CESE's role led to the creation of other connections and empathies, instead of those that would have been important for the successful accomplishment of that delicate balance between images of sameness and otherness I mentioned above. The inclusion of another actor created other empathies and relationships that had nothing to do with Alliance partnerships.

For instance, the dainty banquet CESE organised for the last evening of the event was a celebration of Bahia in all its splendour. The beautiful "ethnic" decoration transforming the sober atmosphere of the Catholic venue, the delicious and "exotic" flavours of the typical dishes and the caipirinhas made of tropical fruits rendered the sensational experience of hospitality into an encounter with Bahia, phrased in the grammar of cultural difference. Talking to the participants during and after the banquet, I encountered many enthusiastic opinions about the way CESE performed its task as organiser, almost invariably followed by the remark that their staff members were the real hosts. In my field notes, I wrote down this phrase pronounced by one of the participants: "the baianos (people from Bahia) did everything. ICCO has just footed the bills".

Alliance authority to control meeting procedures was grounded on the 
difference between hosts and guests. The delegation, however, failed to perform hospitality properly and to mobilise the power of the experience of being together in order to play a role in defining the terms of the negotiation of difference and identification. Moreover, its delegating of practicalities to another actor led to accusations of one of the capital sins in missionary and development work: giving nothing but money, without personal involvement in the work. In my $\mathrm{PhD}$ dissertation I point to the the fact that, when circulating through the KiA network, money may have a dubious character, often obfuscated by (and sometimes even disguised amidst) other relationships and invested with other meanings (Rickli 2010: 220-229). The exoticism of the banquet, which could perhaps be defined as "meridionalism" - as compared to Saïd's orientalism (1978) - conjured meanings that could not be even remotely linked to the Alliance. It exposed, in the broad Bahian daylight, the somehow embarrassing monetary relationship linking givers and receivers.

As I stated in the introduction to this article, cultural or ethnic differences should not be taken for granted as a way to explain encounters, but should rather be approached as ingredients cast out to negotiate oscillation between images of continuity and rupture. In order to achieve a better understanding of this negotiation, I would not only focus on the grammar of difference that is performed in missionary and development encounters, but also address the continuous character of their transnational networks.

In the case of the meeting in Salvador, cultural/ethnical differences between Dutch and Brazilian people should not be taken as a fait accompli capable of explaining the characteristics of the encounter. In my point-of-view, they are just one more component mobilised by the participants in their attempt to make sense of the meeting, whose arena is a continuous world in which sameness and otherness are constantly negotiated. It is not possible to analyse all the complex interactions in the encounter by simply opposing the Dutchness of the delegation to the Brazilianness of the organisations, since a number of representatives of the partner organisations were Dutch people living in Brazil and managing local NGOs, and one member of the delegation was a Brazilian ICCO employee. Not to mention that more than half of the members of the Alliance delegation had lived for many years in Brazil (two of them had grown up in the country), and thus were able, for instance, to sing Brazilian popular songs by heart at evening meetings, over a beer savoured in the garden kiosk. Moreover, the moment in which this grammar of 
cultural difference was most explicitly used was during the banquet celebrating Bahia, whose strong regional accent was equally "exotic" for Dutch and Brazilian participants, a majority of the latter coming from other regions of the country.

The emphasis on engagement and minute interactions does not intend to overlook the strong asymmetries and unbalanced power positions that are inseparable from development encounters, which is one of the most privileged themes analysed by critical sociological and anthropological literature on development cooperation ${ }^{9}$. Recognising the pertinence and importance of this question, my main interest here is to observe how these asymmetrical dispositions are actualised, contested and reproduced in concrete interactions. In this sense, the management of procedures, schedules and time seems to be the fundamental tool used by ICCO Alliance staff to conduct the meeting and to control, in a certain measure, its outcomes. The counterpoint to this way of controlling time and procedures, based on hierarchical positions and institutional power, is the partners' attempts to subvert the official schedules, introducing digressions, delays and improvised debates in the "wrong" moments. The long discussions about the election for the committee that would evaluate and maybe reorganise the schedule of activities is a good indicator of how the management of the practicalities of the meeting is an object of dispute.

\section{Conclusion}

In this text, I described interactions occurred in a meeting of different actors involved with the Dutch Protestant development cooperation network in Brazil, analysing the process of negotiating otherness as an important part of the development endeavour. I introduced the text with an ethnographic vignette depicting a spiritual moment, in which names and faces of the "far-away other" were evoked and incorporated in the liturgical form of the event. In this conclusion, I will return to the vignette to resume the main points of the argument.

The first point I touched upon in the article relates to the importance of the relationship between religion and development, which in the case of

9 Good examples of critical analyses of power dynamics in development encounters can be found in Ferguson (1990), Escobar (1995), Mosse (2005), among others. 
Dutch Protestants is not only based on a common morality of peace and justice, but also on shared histories, as well as common organisational structures and budgets. As I mentioned in the section on ICCO, KiA and the forging of the Alliance, churchgoers in the Netherlands perceive (secular) development cooperation as inseparable from (religious) mission and diaconate. The distinctive character of these domains is their orientation toward the "far-away other". The evocation of names and faces of "people who motivate the fight against injustice" during the rather Christian spiritual moment in Salvador may be seen as an example of how these others are positioned in a given cosmology oriented by this common morality.

In this sense, I propose to analyse development cooperation (and mission) as a mode of relating to otherness (Albert and Ramos 2000: 5-8), which simultaneously organises a transnational network of contacts and fluxes and informs a specific experience of the world and the other for Protestant subjects in the Netherlands. Inspired by the concept originated in the context of native societies of South America, I consider the Dutch Protestant way of organising development cooperation and mission as another example of the infinite variations in the ways that human societies collectively explain, organise and negotiate their relationships with those they consider as being the "other", as belonging to intrinsically different social groups.

The ritual of evoking "real" people, accompanied by gestures, songs and other liturgical practices also points to the importance of the engagement of whole persons in the encounter, the second aspect of the argument I will resume here. I depicted how minute interactions and prosaic details influence the process of negotiating otherness, understood as the accommodation of complex and often paradoxical positions and relations into the cosmologies of development and mission that, through simplified grammars of difference, tend to present ordered and apprehensible panoramas of the world.

On the one hand, the image conjured by the liturgical performance in the spiritual moment, namely, a circle of Dutch and Brazilian "fighters against injustice" pointing to every corner of Brazil and evoking names and faces of the other, did not contradict the grammars of difference orienting the Dutch Protestant development cosmologies. It also ritualises the sense of unity and partnership between ICCO Alliance staff members and the representatives of Brazilian partners. On the other hand, the appeal to "real" people, instead of an abstract and "generic" other, brings to the ritual the issue of engagement. 
The motivation to fight against injustice comes from the engagement with whole persons, people that have names and faces, living in specific "corners of Brazil". It is this proximity with the other that is invoked by the partners every time they need to legitimate divergent and confronting positions and claims, stressing their difference in relation to the ICCO Alliance and their identification with the "real" other.

\section{References}

ALBERT, Bruce and Alcida Rita RAMOS. 200o. Pacificando o Branco:

Cosmologias do Contato no Norte-Amazônico. São Paulo: Unesp.

BERNTS, Ton, Gerard DEKKER and Joep de HART. 2007. God in Nederland: 1996

- 2006. Kampen: Ten Have.

DEKKER, Gerard, Joep de HART and Jan PETERS. 1997. God in Nederland: 1966 1996. Amsterdam: Anthos.

DONK van de, W.B.H.J., A.P. JONKERS, G.J. KRONJEE and R.J.J.M. PLUM.

2006. Geloven in het Publieke Domein: Verkenningen van een Dubbele

Transformatie. Amsterdam: Amsterdam University Press.

DROOGERS, André. 2007. Beyond secularisation versus sacralisation: lessons from a study of the Dutch case. In: K. Flanagan and P. C. Jupp (orgs.) A Sociology of Spirituality. Aldershot: Ashgate. pp. 81-99.

ESCOBAR, Arturo. 1995. Encountering Development: the Making and Unmaking of the Third World. Princeton: Princeton University Press.

FERGUSON, James. 1990. The Anti-Politics Machine: "Development",

Depoliticization, and Bureaucratic Power in Lesotho. Cambridge: Cambridge

University Press.

ICCO. 2006. ICCO Alliance Operational Plan. Utrecht: ICCO.

INGOLD, Tim. 1993. "The art of translation in a continuous world”. In: G. Pálson

(org.), Beyond Boundaries: Understanding, Translation and Anthropological

Discourse. Oxford: Berg. pp. 210-230.

KERKINACTIE. 2006. Jaarverslag. Utrecht: Kerkinactie.

LAW, John. 1994. Organizing Modernity. Oxford: Blackwell.

MOSSE, David. 2005. Cultivating Development: an Ethnography of Aid, Policy and Practice. London: Pluto Press.

QUARLES VAN UFFORD, Philip and Ananta Kumar GIRI. 2003. A Moral Critique of Development: in Search of Global Responsibilities. London: Routledge. 
RICKLI, João. 2010. Negotiating Otherness in the Dutch Protestant World:

Missionary and Diaconal Enconunters between the Protestant Church in the Netherlands and Brazilian Organisations. PhD dissertation. VU University Amsterdam.

SAÏD, Edward. 1978. Orientalism. New York: Vintage.

SALEMINK, Oscar, Anton van HARSKAMP and Ananta Kumar GIRI. 2004. The Development of Religion/ The Religion of Development. Delft: Eburon.

SENGERS, Erik. 2005. The Dutch and their Gods: Secularization and Transformation of Religion in the Netherlands since 1950. Hilversum: Verloren.

STOFFELS, Hijme. 2008. Protestantisme. In: M. ter Borg, E. Borgman, M.

Buitelaar, Y. Kuiper and R. Plum (orgs.) Religie in Nederland - Handboek. Zoetermeer: Meinema. pp. 122-145.

WALLET, Barend. 2005. Samen op Weg naar de Protestantse Kerk in Nederland: het Verhaal achter de Vereniging. Zoetermeer: Boekencentrum.

\section{About the author \\ João Rickli obtained his $\mathrm{PhD}$ degree at the VU University Amsterdam, in October 2010. Since March 2011, he is a postdoctoral fellow at the Pontifical Catholic University of Rio Grande do Sul (PUCRS), in Porto Alegre, Brazil. He is also a member of NER - Núcleo de Estudos de Religião, at the Postgraduate Program in Social Anthropology - UFRGS (Federal University of Rio Grande do Sul). joaorickli@yahoo.com.br R. Dos Andradas, 281, ap. 602 - 90020-ooo Porto Alegre - RS}

